\title{
Opbakning til forfejlede forsørgere!
}

Kønnede ændringer i dansk fattigpolitiks og socialpolitiks uddelingsstrategi 1785-1870

Inger Lyngdrup Nørgård

Nordisk kønshistorie har leveret analyser af, hvordan kønsordningen i I80o-tallets samfund blev søgt genetableret, når kvinder kom ind på et arbejdsfelt eller ind $\mathrm{i}$ en institution, hvor mænd hidtil havde været enerådende eller dominerende. ${ }^{\mathrm{P}} \mathrm{Pa}$ sin vis indfanger denne artikel den modsatte proces. Det var nemlig primært enker, enlige mødre med børn, ugifte kvinder, gamle, syge og børn uden en mandlig arbejdsfør forsørger, der modtog fattighjælp i I700-tallet og første halvdel af i80o-tallet.

Alligevel var det ikke kvinder eller andre af de traditionelle grupper af såkaldt værdige trængende, der ved en række banebrydende danske sociale særlove og tiltag midt i I80o-tallet blev de primære modtagergrupper. Det var derimod ansvarlige men fattige mænd. ${ }^{2}$

Formålet med artiklen er ud fra et kønsperspektiv at afdække ændringer i fattigpolitikkens og socialpolitikkens uddelingsstrategier i forhold til deres modtagergrupper. Jeg argumenterer for, at udpegelsen af de 'værdige' mandlige forsørgere som modtagergruppe af socialhjælp afspejler et nyt tema i uddelingsstrategien. De mandlige forsørgere fik nemlig en helt anderledes - bedre - behandling end den behandling, som fattighjælpsmodtagere såsom kvinder, syge, børn og gamle fik. Hvorfor var det netop en gruppe af 'værdige' uformuende mandlige forsørgere, som udgjorde den nye gruppe af modtagere, der blev knyttet særlige rettigheder til? Ved at trække tre centrale kategorier i fattig- og socialforsorgen frem og afdække hvilke elementer, der over tid konstituerede kategorierne, kan man holde sig køn for øje for at forstå denne inklusion af en ny målgruppe.

\section{Forskningsstatus: fokus på socialt tilhørsforhold}

Anden halvdel af I80o-tallet var en banebrydende tid i dansk og vestlig socialhistorie. Her blev der nemlig givet mulighed for, at udvalgte modtagergrupper fik adgang til at modtage socialhjælp af de offentlige myndigheder, uden at hjælpen blev ydet som fattighjælp. I dansk socialhistorie er historiker Harald Jørgensens værk Studier over det offentlige Fattigvesens historiske 
Udvikling i Danmarki det I9. Aarbundrede fra 1940 et hovedværk. Jørgensen anser 1848 for at være skelsættende i forhold til en ændret behandling af de værdige trængende, da et cirkulære dette år åbnede op for muligheden for at bevilge offentlig hjælp til soldaterfamilier, hvor faderen var i krig. Hjælpen blev ydet uden deklasserende virkninger. Fokus var i cirkulæret og i dyrtidslovgivningen fra I950'erne på at hjælpe de værdigt trængende. ${ }^{3}$ Samme tolkning har økonomen Kjeld Philip i sin bog Staten og Fattigdommen fra 1947. ${ }^{4}$ Andre historikere såsom Anne-Lise Seip i bogen Sosialhjelpstaten blir til: norsk sosialpolitikk $1740-1920$ fra 1984 samt Søren Kolstrup i det nyere flerbindsværk Dansk Velferdshistorie fra 2010 har udledt det samme. 5

I sin forskning om fremvæksten af en amerikansk socialpolitik finder politologen Thecda Skocpol desuden, at krigsveteraner fra den Amerikanske Borgerkrig (I86I-I865) blev banebrydende som modtagere af Amerikas første statslige pension. ${ }^{6}$ Inden for forskning om filantropi har folkloristen Karin Lützen analyseret, hvordan middelstandens kønsbestemte dyder i I80o-tallet via filantropien blev søgt overført til de mandlige arbejdere?

Hvor de nye modtagergruppers værdighedsstatus er fremhævet i forskningen har køn udover i forskning om filantropi ikke fået særlig opmærksomhed i de omtalte bidrag. En del forskning om fattigdomshistorien påpeger dog, at der var en klar overvægt af kvinder, som fik fattighjælp, især i I70o-tallet, men også i i8oo-tallet. ${ }^{8}$ Den amerikanske historiker Rachel Fuchs har således fremhævet, at kvinder var i højere risiko end mænd for at havne $\mathrm{i}$ fattigdom grundet børnefødsler, deres af hængighed af en forsørger, og færre muligheder for at få et arbejde, de kunne forsørge sig ved. ${ }^{9}$

Jeg har tidligere forsket $\mathrm{i}$ opfattelsen og behandlingen af fattige i I700og 1800-tallets København se bogen Beskyt de verdige fattige! Opfattelser og behandling af fattige $i$ velgørenhed, filantropi og fattigvesen $i$ København I770-I874 fra 20I7. I denne forskning blev jeg uden dog at behandle emnet, opmærksom på køn som et implicit parameter, som findes og alligevel ikke synligt findes, i fattigforsorgen. ${ }^{10}$

\section{Køn findes i datidens centrale kategorier i forsorgen}

Denne artikel bidrager med nyt inden for forskning om socialhistorien ved at afdække, hvordan køn og værdighedsaspektet var to parametre, der samvirkede lagde kursen for ændringer i fattig- og socialpolitikkens uddelingsstrategi. I denne artikel er formålet med analysen at sætte spot på, at også køn, var afgørende for at få en privilegeret position i forhold til at få adgang til ressourcer i den redistribution, som socialpolitikkens uddelingsstrategi fastsatte.

Køn er sandsynligvis ikke blevet behandlet tidligere, da køn ikke er 
eksplicit nævnt i fattig- og sociallovgivningen, ligesom oprettelsen af nye fattiginstitutioner ikke for en længere tidsperiode er undersøgt i forhold til, om de var indrettet til grupper af mænd eller kvinder. Det giver ikke mening at anvende et nutidigt parameter som køn for en historiker med materiale fra en tid, hvor køn ofte ikke blev italesat eksplicit. Datidens kulturelle normer for mænd og kvinder, men også for korrekt opførsel og ageren i forhold til social stand, var i mange tilfælde 'selvfølgelige' og uudtalte. For alligevel at kunne afdække køn har jeg identificeret tre kategorier nemlig 'trang', 'værdighed' og 'forsørgerrolle', der har kunnet hjælpe mig med at åbne op for at identificere kønnede ændringer i uddelingsstrategien.

I disse kategorier var der indbyggede kriterier for, om den enkelte fattige kunne inkluderes eller ekskluderes i forhold til at modtage hjælp. Det vil sige, at kategorierne afspejler magtmekanismer i forhold til fordeling af ressourcer. Analysen er bygget op på den måde, at jeg i en række tiltag og aktiviteter i fattig- og socialhistorien i perioden I785-I870 undersøger de argumenter og normer for køn, som konstituerede kategorien i netop det konkrete tiltag. Er den enkelte kategori med til at inkludere eller ekskludere bestemte grupper af mænd eller kvinder fra at modtage hjælp, og med hvilken argumentation? Hvorfor mænd, der netop havde forfejlet at kunne forsørge sig selv og deres familie, bliver den første modtagergrupper af en ikke social deklasserende socialhjælp bliver derved både synlig, men også forstålig.

Kategorien 'trang' er valgt for at afdække og vise, hvordan opfattelser af årsagen til trangen skiftede, og som følge heraf blev det på skift lettere, vanskeligere eller umuligt for forskellige grupper af fattige at få lov til at modtage hjælp. Kategorien værdighed er valgt fordi værdighedsaspektet var virkelig centralt i fattigforsorgen. Hvilke forventninger og elementer skulle de fattige leve op til for at kunne vise sig værdige til hjælp?

Endelig kan kategorien 'forsørgerrolle' anskueliggøre, hvornår den 'værdige arbejdsføre mandlige forsørger' blev inkluderet som modtager af socialhjælp.

Forsørgelse var i ældre tid ofte knyttet til husstanden. Har var herren i husstanden oftest et mandligt overhoved. Det var en pligt for husbonden at sørge for sin kone og sine børn samt sit tyende, også under sygdom. ${ }^{\text {II }} \mathrm{Ud}$ over i husstandstanken forelå også en kulturel norm om, at mænd drog omsorg for forsørgelsen af især de kvinder og børn, som de var i familie med.

At være den part, som var forsørget, synes at være knyttet til en kulturel kvindelighed. Der var en forventning om at blive draget omsorg for af en mandlig voksen forsørger såsom ægtemand, fader, broder eller andet mandligt familiemedlem. Mange kvinder og børn havde dog ingen mandlig forsørger til at forsørge dem, ligesom mange mænd i realiteten ikke kunne eller ville leve op til forsørgeransvaret. 
Mænds principielle forsørgelsesansvar viser sig også i lovgivningen. Retsligt blev fædre gennem en række forordninger i i 700 -tallets anden halvdel gjort økonomisk ansvarlige for deres uægte børn. ${ }^{\mathrm{I} 2}$ I 1800 -tallet fik mænd generelt højere lønninger end kvinder på det fremvoksende offentlige arbejdsmarked såsom for eksempel på skoleområdet med henvisning til deres forsørgerpligt over for familien. ${ }^{{ }^{3} 3}$ Historiker Nina Koefoed betegner det som en maskulin pligt at forsørge sig selv og sin familie, som med introduktionen af Grundloven af I849 fik en retslig understregning, da evnen til at forsørge sig selv og sin familie var en af de kompetencer, som manden skulle leve op til for at være en politisk medborger. ${ }^{14}$

Den maskuline forsørgerpligt gik fra at være en ekskluderende faktor til at være en potentielt inkluderende faktor i forhold til at modtage social hjælp.

\section{Kildemateriale: love, korrespondance, mødereferater og småskrifter}

Kildematerialet består af centrale fattig- og sociallove fra I700- og I800-tallet samt publicerede skrifter og årsberetninger fra både den private velgørenhed og det offentlige fattigvæsen. Desuden inddrages kildemateriale såsom korrespondance og mødereferater fra myndigheder samt privat velgørenhed. De forskellige typer af analyseret materiale er anvendt dels fordi, at i en så lang tidsperiode, som analysen omfatter, flyder den samme materialetype ikke i en så intensiv grad, at man kan anvende den til analysen alene. Dels fordi at det vil være en styrke at undersøgelsen af flere slags kildemateriale kan afdække udsagn, som vil vise, at der sker et skifte i forståelsen af den mandlige forsørger i fattigforsorgen og socialpolitikken. Formålet med artiklen er således ikke at give en dækkende analyse af fattigforsorgen som helhed. Når analysen omfatter en tidsmæssigt set omfattende periode vil der være detaljer og begivenheder udeladt, som kunne være med analysen, men artiklens formål er at afdække en delvis inkludering af mandlige forsørgere i fattigvæsenets uddelingsstrategi, og dette vil kunne påvises i det anvendte materiale. Det samlede materiale indeholder nemlig oplysninger om normative ændringer i fattigforsorgens uddelingsstrategi, italesættelse af modtagergrupper samt argumenter for at hjælpe de fattige. Frem til I80o-tallets midte hjalp det offentlige fattigvæsen mange typer af trængende, og fattigvæsenet hjalp mange børn, udarbejdsføre, gamle og børn, dette vises både i tal og rent retorisk i analysen, hvor inkluderingen af den mandlige forsørger som potentielt værdig trængende afdækkes retorisk i særlove fra midten af I80o-tallet samt i filantropiske aktiviteter i samme periode eller perioden kort efter. 
Analysen omfatter to danske byers fattigforsorg, nemlig Randers og Københavns. Randers var en købstad i det danske rige og havde i I 7873.632 indbyggere, i 18346.407 indbyggere og i 1880 13.457 indbyggere. ${ }^{15}$ København var det danske riges absolut største by og kongens residensstad med cirka 90.000 indbyggere i $1787 \mathrm{og} 133.600$ indbyggere i $1850 .{ }^{16}$ To byer med så forskellig status og befolkningstal har givent en række særlige forhold i deres fattigforsorg. Forcen ved undersøge uddelingsstrategien i begge byers fattigforsorg er, at de ensartede udviklingstræk i de to byers uddelingsstrategi, som afdækkes i analysen, med større sikkerhed vil kunne tilskrives overordnede ændringer i fattig- og socialpolitikkens uddelingsstrategi, idet ændringerne ikke er bundet op på den enkelte bys forsorg. ${ }^{17}$

\section{Traditionelle grupper af modtagere i fattigforsorgen 1785-1799}

For at synliggøre, hvorfor det var skelsættende, at det var de fattige ansvarlige mandlige forsørgere, der blev anerkendt som modtagergruppe af socialhjælp midt i I80o-tallet, vil det være nødvendigt at studere, hvilke modtagergrupper fattigpolitikken i tiden op til midten af 180o-tallet havde en dagsorden om at understøtte.

Efter reformationen i 1536 var kongemagten sammen med de lokale bystyrer ansvarlig for fattigforsorgen, og der blev indført en tydelig forskelsbehandling af de værdige og de uværdige fattige. Kun de værdige fattige måtte tigge og få almisser, de uværdige fattige, som især var de arbejdsføre, blev næg tet hjælp eller tvunget til at arbejde. ${ }^{18}$ Denne skelnen mellem de værdige og uværdige fattige genfindes tydeligt i den danske fattigpolitik i I7oo- og I80o-tallet. Grundlæggende var det sådan, som vi skal se i det følgende, at det var grupper af fattige uden en mandlig forsørger samt kønsmæssigt set blandede grupper af ikke arbejdsføre fattige, der frem til i7oo-tallets slutning blev opfattet som værdige fattige, der kunne opnå fattighjælp.

En plejekommission, som forestod uddelingen af den offentlige fattighjælp i Holmens Sogn i København, beskrev i årsberetningen fra 1798 , hvilke grupper af fattige, der blev tildelt fattighjælp. Plejekommissionen havde:

\section{[...] afviist den Arbeidsføre Dovne, søgt at skaffe den, som vilde arbejde, noget at fortjene, og især ladet den Svage, Gamle, og Umyndige være Genstand for vor Omsorg. ${ }^{19}$}

Citatet viser, at plejekommissionen fokuserede på at yde mest omfattende hjælp til de syge, de gamle og børnene. Det var modtagergrupper, der ikke forventedes at kunne brødføde sig selv. ${ }^{20}$ 
Det fremgår desuden af listerne over fattiglemmer fra årsberetningen fra Holmens Sogns Plejekommission for året I794, at der var en betydelig overvægt af kvinder, ofte ældre, at finde i modtagergruppen. Der var således I99 posteringer under 'voksne fattige' og heraf var I82 kvinder, syv mænd og ti ægtepar. ${ }^{2 r}$

Randers Fattigvæsen fik indtægter fra en række legater, og i en oversigt over legater doneret frem til I803 kan man fastslå hvilke typer af fattige, der skulle være legatmodtagere. De var følgende: fattige, husarme, trængende enker, fader- og moderløse pigebørn, slægtninge til donator, enker, fattige børn, fattige enker og svagelige jomfruer. Et enkelt legat blev givet til enkemænd. ${ }^{22}$ Modtagergrupperne afspejler et fokus på at donere til kvinder og børn uden en arbejdsfør forsørger. Desuden nævnes de husarme som en særlig modtagergruppe blandt de andre. De husarme var en særlig type fattige, som havde rod i middelstanden og derfor var fattige i den forstand, at de ikke kunne praktisere den livsførelse, der blev forventet af dem. Tilhørsforholdet til middelstanden gjorde dem værdige til at modtage hjælp. ${ }^{23}$

Både i Randers og København var fattigvæsenernes indretning i slutningen af I700-tallet påvirket af patriotiske strømninger, og overbevisningen var, at staten ikke bare skulle understøtte de fattige børn, gamle og syge, men også skulle hjælpe de arbejdsføre og arbejdsvillige fattige mænd og kvinder ved at sætte dem i arbejde. ${ }^{24}$ Det var dog børn, syge og gamle, der havde de lokale fattigvæseners største bevågenhed.

Trangs- og værdighedskategorierne samvirkede dermed i fattigpolitikkens uddelingsstrategi overordnet set således, at den fattige var værdig til hjælp, hvis dennes trang var forårsaget af manglende mulighed for fysisk at kunne arbejde eller en manglende mandlig forsørger. Heraf det vægtige fokus på, at børn, kvinder og især enker, skulle hjælpes. Forsørgerrollen virkede i denne uddelingsstrategi ekskluderende på de fattige mænds mulighed for at modtage hjælp.

\section{Større diversitet i fattigforsorgens modtagergrupper 1800-1848}

I årene omkring I80o fik Danmark tre fattiglove gældende for København (1799), købstæderne (1803) og landet (1803). For Københavns vedkommende betød den nye fattiglovgivning, at alle fattige, der havde boet i byen $\mathrm{i}$ tre år, i princippet kunne få tildelt fattighjælp. Lovens intention var at sikre, at de fattige blev understøttet $i$ at være gode arbejdere. ${ }^{25}$

Fattigforordningen af $\mathrm{i} 803$ for købstæder gjaldt for Randers, og forordningen indførte en pligt til at understøtte alle virkeligt trængende. ${ }^{26} \mathrm{De}$ trængende skulle inddeles i tre klasser. ${ }^{27}$ 
Omfanget af hjælp, der var knyttet til de tre klasser, afspejler stadig den logik i fattigpolitikken, at de, der ikke havde en forsørger, samt de, der manglede arbejdsførlighed, havde ret til en højere grad af assistance. Igen nævnes køn ikke eksplicit i lovgivningen hverken for København eller Randers i forhold til modtagergrupperne.

Ved indførelsen af disse fattiglove, hvormed der også fulgte en mulighed for at udskrive fattigskat, antog hjælpen til de fattige nu i højere grad end tidligere en form af social pligt snarere end en kristen pligt, og der blev der åbnet op for at opstille en række krav til de fattige. I første halvdel af I8oo-tallet blev det at modtage offentlig fattighjælp forbundet med en række deklasserende retsvirkninger, hvoraf de centrale var, at fattiglemmer ikke måtte sælge eller pantsætte deres ejendele (I808), eller indgå ægteskab uden fattigvæsenets accept (1824), og at forsørgelsesret først kunne opnås efter fem års ophold i en kommune i stedet for efter tre år (I839). Desuden blev mandlige fattiglemmer ekskluderet fra deltagelse i det politiske liv med Grundloven (1849). Samtidig var fattiglemmerne underlagt fattigvæsenets bestemmelser om muligheden for at indskrive dem på en arbejdsanstalt eller fattiginstitution, hvorved familier kunne risikere at blive adskilt. ${ }^{28}$

I begyndelsen af I80o-tallet var der en stor overvægt af kvinder under det københavnske fattigvæsens forsørgelse: I I807 var der således i alt 8.978 fattiglemmer, og kvinderne udgjorde 51,9 procent, hvor mænd kun udgjorde I4,5 procent, mens 33,6 procent var børn. ${ }^{29}$

De fattige blev i større omfang institutionaliseret i i 800 -tallet. For eksempel fik Randers i I8I9 en arbejdsanstalt, der skulle sikre, at de arbejdsføre fattige ydede noget..$^{30}$ Københavns Fattigvæsen fik i 1822 mulighed for at sende hjemløse og lediggængere på en forsøgsarbejdsanstalt, Ladegaarden.$^{3 \mathrm{~T}}$ Fælles for disse nyindførte institutioner i Randers og København var, at de også rettede sig mod arbejdsføre mænd. Dog var der stadig i i819 en klar overvægt af kvinder blandt de indskrevne voksne fattige under det københavnske fattigvæsen, således udgjorde kvinderne 82,I5 procent og mændene 17,85 procent. $^{32}$

I Randers var der i i 818 også en klar overvægt af kvinder. I alt 75 fattige fik fattighjælp, og det drejede sig om 58 kvinder, to ægtepar, et barn samt I4 mænd. ${ }^{33}$ I de efterfølgende år udlignede kønsforskellen sig dog, og der var for eksempel i I847 næsten lige så mange mænd som kvinder blandt fattighjælpsmodtagerne. ${ }^{34}$

Det voksende fokus på mænd afspejler sig også i debatten om fattigforsorgen. Flere fremhævede, at de værdige fattige, såsom stræbsomme men fattige mandlige håndværkere, burde sikres en bedre behandling end såkaldt uværdige dovne, drikfældige, fattige mænd. ${ }^{35}$ Dermed kan det udledes, at der var opstået en ide om, at mænd, der udviste stræbsomhed, arbejdsomhed 


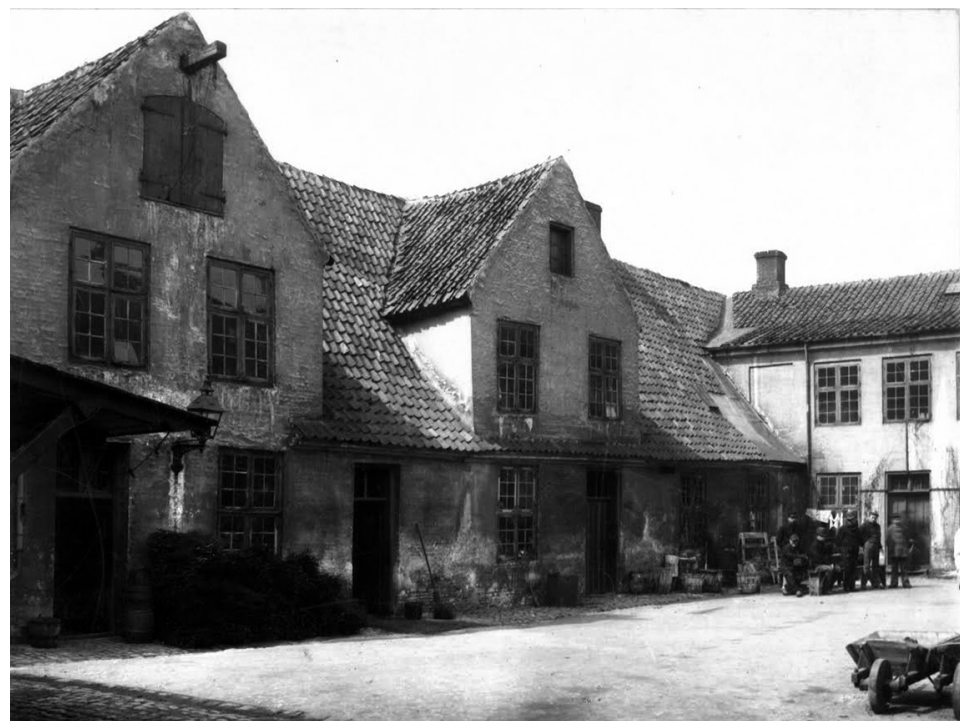

Her ses en del af Ladegårdens gårdparti anno 1895. Ladegården var Københavns Fattigvæsens arbejds- og tvangsinstitution. Formålet med Ladegården var i dens begyndelse at sætte arbejdsføre fattige, især mænd, i arbejde, - de var nemlig farlige at have gående rundt i det københavnske bymiljø. (Foto: 1895. Frederiksberg Stadsarkiv).

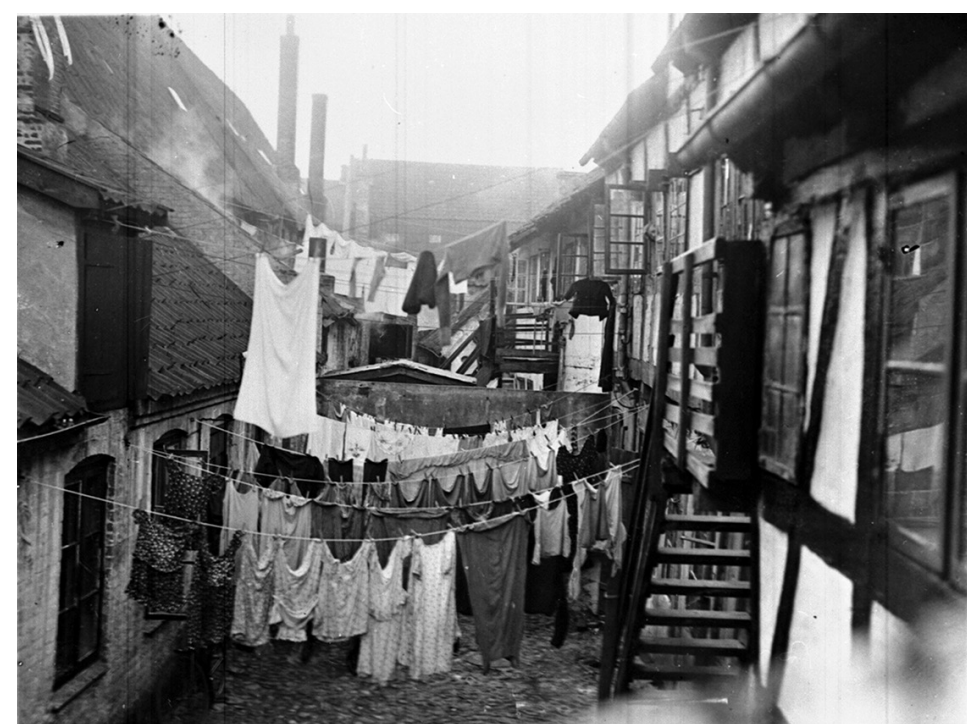

Dette foto viser Trangstræde i Randers midtby. Den slidte boligmasse bestod i høj grad af huse fra 1800 -tallet. Boligmassen fik lov at bestå frem til saneringstiden i 1960'erne. Her fås et glimt ind i en 1800-tals gade, hvor fattige trængende kan have mødt filantropiske velgøreres idealer. (Foto: ca. 1939. Randers Stadsarkiv). 
og ædruelighed, som var middelstandens dyder, burde ydes en bedre hjælp end de uværdige trængende, der selv var skyld i deres fattigdom. ${ }^{36}$

Selvom der i første halvdel af i8oo-tallet dermed voksede en større diversitet frem i forhold til, hvem der skulle modtage fattighjælp ifølge uddelingsstrategien, gjorde den grundholdning sig stadig gældende, at kvinder, børn, syge og husarme var særligt værdige til hjælp. ${ }^{37}$ Mændene blev for eksempel heller ikke eksplicit nævnt som potentielle modtagere af en række legater, der blev oprettet i perioden 1800 til I850 i Randers. ${ }^{38}$

\section{Krigsinvalider og afdøde forsørgere}

Danmark kom i krig i I848 i den såkaldte Tre-årskrig. En kreds af det københavnske borgerskab oprettede i den forbindelse den I. maj I848 en filantropisk forening, Centralkomiteen af I848, der havde til formål at yde understøttelse til nationens faldne soldaters efterladte, de hjemsendte sårede, samt soldaterfamilier, hvor faderen var i krig. Centralkomiteen forklarede, at krigen holdt mange familieforsørgere fra hjemmet, og nogle familier befandt sig endda i den situation, at deres forsørger var død. Andre soldater vendte hjem fra krigsdeltagelsen i en så dårlig forfatning, at de ikke kunne varetage deres forsørgerpligt. Soldaterne blev omtalt som modige og brave, da de var villige til at ofre blod og liv for det fælles fædreland. ${ }^{39}$ Krigen havde således forhindret en række forsørgere $i$ at varetage deres forsørgerpligt, og samtidig blev soldaterne italesat som så respektable $\mathrm{i}$ deres nød på grund af krigsindsatsen, at de og deres familier burde hædres og få en anden behandling end de sædvanlige fattige under det offentlige fattigvæsen. I argumentationen blev krigsdeltagelsen italesat som at udvise fædrelandskærlighed og opofrelse.

Det der afgør værdigheden i vurderingen af den sårede eller faldne soldats værdighed til hjælp, viser sig $i$ argumentationen, nemlig at der var opbakning til forsørgerrollen samt en accept af, at uformuende mænd, var en del af den kreds af mennesker, der kunne være værdige medborgere.

Argumenterne viser, at de tre kategorier trang, værdighed og forsørgerrolle underbygges med andre forhold end hidtil og relateres til hinanden på en ny måde. Trangen vurderes ikke som i den traditionelle fattigpolitik i forhold til arbejdsduelighed eller ideen om, at forsørgeren burde kunne forsørge sig selv og sin familie, men i stedet italesættes trangen som ikke selvforskyldt hos soldaterne, der agerede som ansvarlige medborgere og forsvarede fædrelandet. Hermed var de særlig værdige i deres nød. Samme logik er af Theda Skocpol påpeget i forskning om den amerikanske socialpolitiks ophav i understøttelsen af krigsveteraner. Soldater blev berøvet 
muligheden for at varetage deres forsørgerrolle, hvilket blev betragtet som et problem, samfundets andre medborgere kunne være med til at løse..$^{\circ}$ Løsningen var, at soldaterne og deres familier ikke skulle behandles som de sædvanlige fattige, men derimod modtage socialhjælp, der holdt dem ude af det deklasserende fattigvæsen.

Denne løsning fandt også opbakning hos de danske myndigheder. Den 29. maj 1848 udsendte Justitsministeriet et cirkulære, der gav sogneforstanderskaber bemyndigelse til at hjælpe soldaterfamilierne uden at dette blev betragtet som fattighjælp. I den danske socialhistoriske forskning anses cirkulæret for at være udtryk for en ændret dagsorden i dansk socialpolitik, idet ikke al socialhjælp fra det offentlige længere blev givet gennem fattigvæsenet. ${ }^{4}$

Imens Tre-årskrigen fandt sted, gik Danmark fra at være et enevældigt monarki til at være et konstitutionelt monarki med indførelsen af Grundloven i r849. I samtiden blev det opfattet som mest rigtig også at tildele politiske rettigheder forstået som valgret til de soldater, der kæmpede for fædrelandet. Hermed fik en bred kreds af uformuende mænd politiske rettigheder. ${ }^{42}$

For at få politisk valgret var det ifølge Grundloven et kriterium, at manden kunne forsørge sig selv og sin familie, da modtagere af offentlig fattighjælp var ekskluderet fra politisk valgret. Samtidig indeholdt Grundloven en ret til de fattige til at modtage social hjælp uanset årsagen til trangen. ${ }^{43}$ Grundlovens bestemmelser udtrykte dermed, at alle skulle have ret til hjælp, men at det ikke at kunne varetage forsørgerrollen ekskluderede mænd fra politisk valgret.

Efter Tre-årskrigens afslutning i 185 blev Centralkomiteen af I 848 ophævet, og foreningens midler og understøttelsesforpligtigelser blev overdraget til en Invalidebestyrelse (1851). Der var ønske om at tage hånd om krigsinvaliderne, som indførelsen af invalidepension efter krigen er udtryk for. Debatten i Rigsdagen om invalidepension drejede sig om, at Danmark havde en pligt til at takke soldaterne for deres mod, tapperhed, disciplin og selvfornægtelse. En måde at gøre det på var at opfylde folkets og hærens $ø$ nsker om at understøtte invaliderne eller de dræbte soldaters efterladte familier. Deres skæbne var ellers uvis. ${ }^{44}$ Folketingsmedlem professor C. E. Fenger udtalte følgende:

Soldaten maa vide, at naar han gaaer i Slag og udsætter sig for Fjendens Kugler, da vil han, hvis han skulde komme til at miste sine Lemmers Brug og sin Arbeidskraft, som er hans hele Rigdom, derfor ikke blive til nogen Stodder, og han maa vide, at, dersom, han skulde falde, ville hans Enke og Børn derfor ikke være hjælpeløse. ${ }^{45}$ 


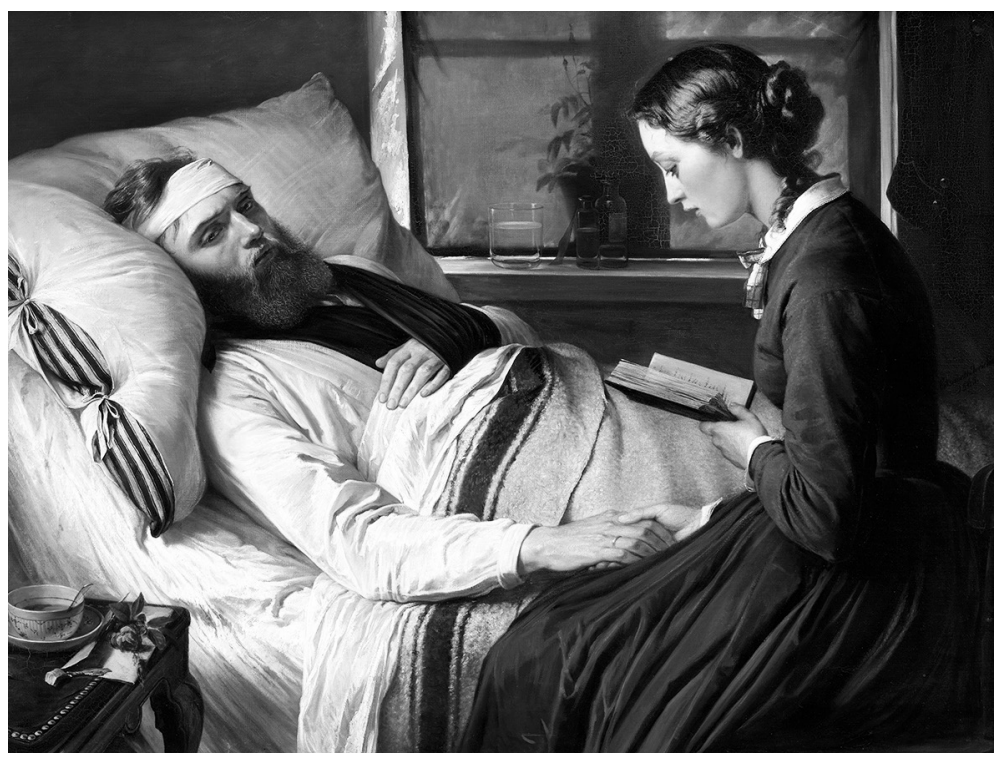

Dette stemningsfulde maleri har titlen En såret dansk Kriger, 1865. Maleriets motiv henviser til nederlaget ved Dybbøl Banke i Krigen i 1864. Tre-Årskrigen (|848-5I) og krigen i I 864 blev banebrydende for fortællingen om den danske nation. En række private medborgere samlede i løbet af begge krige midler ind for at hjælpe de sårede soldater og de afdøde soldaters familier med en argumentation om, at alle, der forsvarede fædrelandet, var værdige til social assistance uden om det offentlige fattigvæsen. (Maleri: Elisabeth Jerichau Baumann, En såret dansk Kriger, 1865, 1865. Statens Museum for Kunst).

Hvis den fysiske arbejdsførlighed var forringet eller helt fraværende, kunne mændene ikke forsørge sig selv, og her burde staten overtage soldatens forsørgerpligt. Enkelte i debatten fremhævede, at mandens forsørgerpligt også kunne omfatte søstre, mormødre og forældre. Det blev italesat, at det ikke ville være i orden, hvis de fysisk svækkede krigsinvalider grundet krigsdeltagelsen endte som betlere eller fattighjælpsmodtagere..$^{4}$ Lovforslaget om invalidepension, der gav krigsinvaliderne en anderledes bedre behandling end fattighjælpsmodtagerne, fik bred opbakning i Rigsdagen og blev vedtaget den 9. april 1851.

Danmark kom på ny i krig i i864. Igen reagerede civilsamfundet og de offentlige myndigheder med at lave en social indsats. Der var fra officiel side den I7. december I863 udstedt en såkaldt foreløbig lov om forsørgelse af indkaldte soldaterfamilier. Loven skulle hindre, at indkaldte soldaters familier, der kom i trang, fordi forsørgeren var borte fra hjemmet, kom under det almindelige fattigvæsen. Derfor skulle landets kommuner yde hjælp til "Fædrelandsforsvarerens Hustruer og Børn”. ${ }^{47}$ I Randers var kommunalbestyrelsen på forkant med udviklingen, da den randrusianske 
komite afholdt sit første møde den Ir. december 1863. Komiteen besluttede at overtage forsørgelsen af fattige fra fattigvæsenet, hvor det ifølge lovens bestemmelser var muligt. ${ }^{4}$

Komiteen i Randers modtog også anmodninger om hjælp. For eksempel ansøgte den indkaldte soldat M. Wellow i et brev den $\mathrm{I6}$. december I863, om Komiteen ville yde økonomisk hjælp til hans tilbageladte forældre hjemme i Randers. Wellow plejede at forsørge dem, men han var forhindret grundet hans indkaldelse, og han forklarede, at forældrene nødigt ville være tvunget til at søge offentlig fattighjælp. ${ }^{49}$

I forbindelse med krigene og de dertil knyttede tiltag var det afgørende kriterium for at være værdig til at modtage social bistand uden om fattigvæsenet, at man var soldat eller under en soldats forsørgelsesansvar. Kun mænd var soldater, og kvinder var som følge heraf umiddelbart ekskluderede, medmindre de var under en soldats forsørgelse. Køn var afgørende i forhold til at modtage hjælp, hvorimod socialt tilhørsforhold til middelstanden ikke var afgørende for at modtage hjælp.

\section{Den økonomisk pressede forsørger}

Hvor aktiviteterne under krigene centrerede sig om at overtage den mandlige forsørgers kulturelle forsørgerpligt overfor ham selv og familien, når han blev berøvet forsørgerevnen, var en anden logik på spil i den midlertidige dyrtidshjælp. I I850'erne var der dyrtid i Danmark, hvilket betød, at der var høje priser på fødevarer og udbredt arbejdsløshed. Den I4. november I853 gav Rigsdagen kommunalbestyrelser landet over bemyndigelse til midlertidigt at uddele hjælp til uformuende, uden at hjælpen blev betragtet som fattighjælp og havde deklasserende virkninger. Herved blev der også klart åbnet op for en forståelse af, at ikke al trang var selvforskyldt. To gange mere blev dyrtidslovgivningen vedtaget, nemlig i februar 1855 gældende for et år, og i januar 1856 denne gang gældende for to år..$^{\circ}$ Dyrtidslovgivningen er som nævnt i forskningsgennemgangen tolket som et udtryk for, at nogle fattige blev anset for at være for vardige til at skulle modtage offentlig fattighjælp i en ekstraordinær situation med dyrtid.

Dyrtidslovgivningen fra I850'erne var i sig selv ikke eksplicit i forhold køn, når det gjaldt hvem, der kunne være modtagere. Lovgivningen udnævnte modtagergruppen til at være de "uformuende", der normalvis kunne arbejde sig til et levebrød, og som kun var i nød på grund af dyrtiden. Det var disse brede kriterier, at være uformuende, ramt af dyrtiden og normalt at kunne forsørge sig selv, som blev stillet op rent lovgivningsmæssigt for at kunne modtage hjælpen. Hvilke trængende, der levede op til kriterierne, var der efterladt et bredt tolkningsrum for at afgøre på lokalt niveau. 
I Rigsdagens forhandlinger om vedtagelsen af dyrtidslovgivningen fremgår det dog tydeligt, at fokus i dette forum ikke var på at hjælpe kvinder men på med medlemmernes eget ordvalg at hjælpe arbejdere, husmænd, håndværkere, daglejere eller fiskere..$^{\mathrm{I}}$ Det var således implicit forstået de fysisk arbejdsføre uformuende mandlige forsørgere, Rigsdagens mænd udtrykte bekymring for. Forsørgerrollen er vigtig, men nu med en anden betydning end den ekskluderende i tidligere tiders fattigpolitik: her fungerede forsørgerrollen som en inkluderende faktor for at få hjælp.

I København blev dyrtidslovgivningen indledningsvis ikke anvendt, og en forening som Håndverkerforeningen, som bestod af større mestre, anmodede Københavns Borgerrepræsentation om at anvende loven til gavn for "Middelclassen af Byens Indvaanere og navnligen Haandværkerstanden".52 Nogle i samtiden opfattede således lovgivningen som rettet mod uformuende af middelstanden. Borgerrepræsentation endte med at lade ekstraordinær hjælp uddele på grund af dyrtiden og sikre, at modtagernes "borgerlige rettigheder" ikke blev påvirket. ${ }^{53}$

Hvis man var en værdig medborger, der levede økonomisk forsvarligt, påtog sig forsørgerrollen, havde borgerlige rettigheder og socialt set hørte til i middelstanden, burde man have adgang til hjælpen.

Denne kobling til det politiske medborgerskab bekræftes i samtidens retorik, hvor det blev betonet, at midlertidig hjælp til de uformuende værdige fattige kunne redde disse fra et afskrækkende offentligt fattigvæsen og fra at blive stemplet som andenrangs medborgere uden borgerlige rettigheder. ${ }^{54}$

Randers Borgerrepræsentation fik etableret et samarbejde mellem byens fattigkommission og en privat velgørende forening, Velgørenheds Selskabet, om at udpege modtagergrupper af dyrtidshjælp. .5 I Randers var der velvilje og samarbejde mellem fattigforsorgens eksisterende aktører, hvilket kan have bevirket, at man hurtigere fandt frem til de lokalkendte værdige trængende, hvoriblandt der givetvis var kvinder, da privat velgørenhed på dette tidspunkt ofte hjalp kvinder, børn og husarme. ${ }^{56}$

Dyrtiden bevirkede også, at lokale myndigheder som kommunalbestyrelserne fik mulighed for at give dyrtidstillæg til de mindre vellønnede stillinger i staten såsom arrestforvarere, politibetjente, skolelærere, etc. Denne mulighed blev det ved afstemning på et møde i den 23. januar I854 i Randers kommunalbestyrelse vedtaget at benytte. I forbindelse med uddelingen af dyrtidstillæg blev det drøftet i kommunalbestyrelsen, om gifte mænd skulle have fortrinsret til hjælpen, og her må det uudtalt have været den forsørgerpligt, som manden skulle varetage overfor familien, som man ville bakke op om. ${ }^{57}$

I $1850-$-ernes dyrtidslovgivning fremstod modtagergruppen i lovgivningen kønsneutral, men i forhandlinger i Rigsdagen, i civile foreningers ageren 
samt i administrationen aftegner sig et fokus på at hjælpe den mandlige forsørger med at varetage sin forsørgerposition.

\section{Filantropiens opbakning til den respektable arbejder}

Hvor de foregående afsnit især omhandler de banebrydende særlove, der åbnede op for offentlig hjælp uden fattighjælpens retslige virkninger, så handler dette afsnit om den private velgørenhed og filantropi. I første halvdel af I80o-tallet blev den private velgørenhed skilt ud af den offentlige fattigvæsen, konkluderer historiker Inger Lyngdrup Nørgård. ${ }^{8}$ Hermed var grundlaget for en to-deling af socialforsorgen hvortil var knyttet forskellige arbejdsopgaver mulig. Dette er loven om De Fattiges Kasse (I856) et udtryk for. Her deltes fattigforsorgen i Danmark lovgivningsmæssigt i to grene; én efter samtidens opfattelse tvungen skattebaseret fattigforsorg og én fri fattigforsorg. Den frie fattigforsorg var i princippet baseret på velgørende bidrag og skulle eksistere som et supplement til det officielle fattigvæsen. Loven om De Fattiges Kasse var udtryk for den efterhånden udbredte opfattelse, at nogle trængende var for vardige til det officielle fattigvæsens understøttelse. Særligt ved den frie fattigforsorg såvel som filantropien var, at dens modtagere ikke blev ramt af den offentlige fattighjælps retslige deklasserende virkninger såsom tab af politisk valgret og eventuel indsættelse på institution, og et af den private fattigforsorgs formål blev også åbent formuleret til at være, at man ville holde værdige trængende ude af det demoraliserende offentlige fattigvæsen.

De Fattiges Kasses modtagergruppe var de trængende, der forsøgte at leve som produktive og stræbsomme borgere, men var blevet ramt af sygdom, arbejdsløshed eller personlige tragedier. Heri lå en opfattelse af, at man kunne være værdigt trængende, når man var ramt af ydre ulykker. ${ }^{59}$

I anden halvdel af I80o-tallet gennemgik filantropien en professionaliseringsproces. Mange typer af fattige såsom børn, handikappede, kvinder, syge, gamle, håndværkere og arbejdere fik hjælp gennem filantropien. ${ }^{\circ}{ }^{\circ}$ En af kategorierne blandt de værdige trængende var de mandlige arbejdere, dette afspejler, at strategien i den gryende socialpolitik om at gøre de respektable fattige mandlige forsørgere til en særlig modtagergruppe også fandt sted inden for filantropiske aktiviteter.

I en diskussion i 1866 i et udvalg under den københavnske filantropiske forening, Centralkomiteen af I864, fremhævede lægen F. F. Ulrik, at filantroperne burde hjælpe med at oprette sparekasser, sygekasser og alderdomsforsikringer til arbejderne. Et medlemskab i disse kunne være med til at sørge for, at arbejderne kom ud af fattigdommen og samtidig udviste en vilje til selvstændighed. At fattige kvinder og børn i høj grad blev forbigået med 
hjælp i disse tiltag, noterede Ulrik som et problem. Han forholdt sig dog ikke yderligere til den kønsmæssige skævhed i disse hjælpeforanstaltninger ${ }^{6 r}$

I Randers kom filantropien blandt andet til udtryk ved oprettelsen af Randers almindelige Understottelsesforening (1868). Foreningen hjalp mandlige arbejdere med aktiviteter, men en broget gruppe af syge, gamle, enker og børn modtog også understøttelsesforeningens hjælp. Hjælpen, der var rettet mod de mandlige arbejdere, bestod i forskud og rentefri lån samt tildeling af arbejde som gruskastning og stenslagning. ${ }^{62}$

Understøttelsesforeningen opfordrede byens arbejdere til at melde sig ind i en sygekasse og sparekasse, da

...enhver yngre og arbeidsdygtig Familieforsørger bør bringes til at indsee, at det er hans Pligt at benytte Sparekassen og Sygekassen, og at han ikke har gjort, hvad han kunde og burde, saalænge det ikke er skeet. Disse to Dele bør være ham lige saa vigtige som Føde og Klæder og Huusly. ${ }^{63}$

Citatet viser, at familieforsørgeren skulle udvise økonomisk ansvarlighed og være arbejdsom for at blive vurderet som værdig $\mathrm{i}$ sin nød. Man kan udlede, at det at forsøge at leve op til middelstandens dyder såsom sparsommelighed og arbejdsomhed var et kriterium for at være en del af det fremvoksende borgersamfund.

I den filantropiske forening, Kjøbenhavns Understottelsesforening (1874), genfindes en endog meget samstemmende tilgang til at hjælpe de mandlige arbejdere.$^{64}$ Kønsfordelingen blandt de, som modtog understøttelse fra denne forening i I874, var således, at mænd udgjorde henholdsvis 36 procent, 42 procent, 45 procent og 53 procent af de understøttede i fire af understøttelsesforeningens i 4 lokale afdelinger. Der findes ikke kønsspecifikke oplysninger fra de andre afdelinger. ${ }^{65}$

Nyere forskning understøtter at fattige mandlige forsørgere i perioden efter indførelsen af Grundloven var indsats for en særlig hjælp, ikke bare inden for filantropien, men også inden for det offentlige fattigvæsen. Historikerne Nina Koefoed og Leonora Lottrup Rasmussen opererer med et kønsperspektiv $\mathrm{i}$ undersøgelser af politisk medborgerskab og herigennem afdækkes det, at en gruppe af fattige mandlige forsørgere fra arbejderklassen $\mathrm{i}$ anden halvdel af I80o-tallet fik forskellige former for hjælp af det offentlige fattigvæsen i byen Århus. Modtagelsen af fattighjælp fik ikke de ellers vanlige retslige virkninger såsom tab af politisk valgret og anden form for selvbestemmelse. Hjælpen synes at være givet som en belønning til de forsørgere, der søgte at forsørge en familie, også for at sikre dennes forsørgelse. ${ }^{66}$ 


\section{Inklusion af 'forfejlede' mandlige forsørgere i socialpolitikken}

I ovenstående historiske analyse blev den kønsmæssige udvidelse i midten af I80o-tallet i uddelingsstrategien væk fra uforsørgede kvinder og hen imod også at have et fokus på de trængende mandlige forsørgere belyst gennem en undersøgelse af de forhold, som løbende konstituerede kategorierne trang, værdighed og forsørgerrolle. Det har vist sig i analysen, at kategorien 'forsørgerrolle' var central, da den gik fra at have en ekskluderende virkning for de mandlige arbejdsføre forsørgere i forhold til at få fattighjæelp til at virke inkluderende i midten af I80o- tallet i de behandlede sociale aktiviteter. Igennem kategorien forsørgerrolle tematiseres det, at der skete en delvis inkludering af den mandlige forsørger som værdig trængende, der kunne modtage særlig hjælp af det offentlige eller den private velgørenhed uden rettighedstab. Når der er tale om en delvis inkludering skyldes det, at kategorien 'forsørgerrolle' samt kategorien 'værdighed' kobles, så begge kriterier skal være opfyldt for, at forsørgeren var acceptabel som modtager. Kategorien værdighed blev i de sociale love i midten af i80o-tallet baseret på at kriterier som at forsvare fædrelandet eller udvise middelstandsværdier. Dertil kom der et ændret syn på trangsårsagerne, hvor synet på de arbejdsføre mandlige forsørgere i første del af den behandlede periode var, at de burde kunne arbejde sig til et levebrød. Der opstod som beskrevet i midten af I80o-tallet en opfattelse af, at også arbejdsføre mænd kunne komme ud for faktorer såsom høj arbejdsløshed, dyre fødevarer og lignende, som gjorde det vanskeligt at arbejde sig til et levebrød. Kategorierne forsørgerrolle, værdighed og trang samvirkende og etablerede socialpolitikkens nye modtagergruppe, de værdige uformuende mandlige forsørgere.

Forskning om fremkomsten af et spædt demokrati i Danmark, kan give en forklaring på den ændrede behandling af de respektable, men fattige, mandlige forsørgere. Med indførelsen af den delvist demokratiske Grundlov i 1849 gik samfundets styrelse formelt set til en række ansvarlige og myndige mænd. ${ }^{67}$ Ifølge historikeren Nina Koefoed blev adgangen til valgret baseret på personlige kompetencer. De personlige kompetencer blev vurderet i forhold til, hvordan kompetencerne gavnede samfundet. Den mandlige forsørger blev i midten af I8oo-tallet således medborger via pligtrelationen til samfundet.$^{68}$ De mandlige forsørgere stod også tidligere i et ansvarsforhold overfor hushold og familie, men hvor mændene tidligere alene mistede status og muligheder, når de ikke levede op til forsørgerrollen, skete der det med introduktionen af Grundloven og de sociale love, at de mandlige forsørgere blev honoreret, når de forsøgte at udfylde forsørgerrollen ved at udfylde de vedtagne kompetencer. Det kan tolkes som en overgangsfase i det danske 
samfund, hvor man gik fra at fokusere på undersåtter og stand, til at forsørgerne uanset social stand indtog en ny rolle som moderne repræsentanter. I forlængelse heraf bliver den positive særbehandling af de værdige fattige mænd forståelig. De pligter, som den enkelte medborger skulle honorere for at leve op til at være en værdig medborger blev knyttet til kulturelt set mandligt konnoterede arbejdsopgaver, som bar på middelstandens værdisæt såsom arbejdsomhed, sparsommelighed, renlighed og en ansvarstagen for familie samt nationen. Så længe mændene tilstræbte at efterleve de rette kompetencer, blev de inkluderet i det mandlige medborgerskab. Disse ansvarlige medborgere blev belønnet, men også 'bevaret', gennem socialhjælp. Dette kan tolkes som et udtryk for en begyndende socialpolitik, som fordelte sociale ydelser, der havde til formål at bevare eller anerkende ansvarlige og værdige medborgere. Ved socialpolitik kan forstås kollektive foranstaltninger, som skulle afhjælpe samfundsmæssigt anerkendte sociale problemer hos borgerne. ${ }^{69}$

De fattige men værdige mænd, som nærværende artikel har taget under behandling, udgjorde en yderliggruppe i forhold til datidens fuldt selvforsørgende mænd, som kan siges at repræsentere en normsættende gruppe. Samtidig var gruppen af fattige og værdige mænd selvsagt mere anerkendt end de fattige mandlige lediggængere og hjemløse.

Kan man tale om, at det var et normbrud i forhold til fattigpolitikken, at de mandlige forsørgere, der fejlede i forhold til at leve op til selvforsørgelse, blev inkluderet som selvstændige medborgere via socialhjælp? I hvert fald fremstår denne nye gruppe af modtagere som en nyetableret kønsmæssig førstehed med særlige privilegier inden for den sociale forsorg i forhold til både kvinder og de fattighjælpsmodtagende mænd.

\section{Konklusion}

Det kan konkluderes, at fattigpolitikken i I7oo-tallet og første halvdel af I80o-tallet havde en principiel grundlæggende uddelingsstrategi, der foreskrev, at den personlige værdighed var knyttet til manglende fysisk mulighed for at arbejde, samt at børn og enker uden mandlig forsørger skulle hjælpes. I denne strategi var de fattige arbejdsføre mandlige forsørgere absolut ikke en kernemodtagergruppe. Det fremgår i studierne af kildematerialet, at samtiden ikke fandt behov for at forklare eller argumentere for, hvorfor uddelingsstrategien var sådan.

I første halvdel af I80o-tallet fandt der dog et begyndende opbrud sted i forståelsen af hvem, der burde modtage hjælp, og under hvilke former, hjælpen skulle modtages. Nogle indtog den holdning, at de mere værdige fattige, heriblandt stræbsomme mænd med middelstandsdyder, skulle sikres 
en bedre behandling. Der begyndte også at brede sig en opfattelse af, at det kunne være udefra kommende faktorer, såsom krig, dyrtid eller udbredt arbejdsløshed, som bevirkede, at trangen ikke alene var den nødstedte og fattiges egen skyld.

Nærværende artikels analyse indkredser ud fra et kønsperspektiv, hvordan kategorierne 'trang', 'værdighed' og 'forsørgerrolle' blev konstitueret i forhold til de behandlede sociale love og tiltag midt i r8oo-tallet. Parameteret køn viser sig især i kategorien 'forsørgerrolle', der gik fra at have en ekskluderende virkning for mænd i forhold til at modtage social hjælp til at have en inkluderende virkning. Det var nemlig de mandlige respektable forsørgere, der blev italesat som primær målgruppe for de nye sociale love. Hvor den socialhistoriske forskning har peget på, at det nye i forhold til modtagergruppen ved indførelsen af de sociale love var, at modtagergruppen bestod af de værdigt trængende, der skulle modtage offentlig assistance uden rettighedstab, så har nærværende analyse afdækket, at parametrene køn og værdighedsstatus tilsammen etablerede en ny modtagergruppe i socialpolitikkens uddelingsstrategi, nemlig de værdige fattige mandlige forsørgere.

Denne kønnede ændring i uddelingsstrategien væk fra primært i begyndelsen af den behandlede periode at fokusere på at drage omsorg for de uforsørgede kvinder og hen i mod en klar tematisering i midten af r8oo-tallet til at også at anerkende ansvarlige mænd som værdige modtagere i uddelingsstrategien, kan tolkes som et udtryk for en begyndende socialpolitik. En socialpolitik som sikrede sociale ydelser, der havde til formål at bevare respektable medborgere. Når mændene tilstræbte at efterleve de rette kompetencer, nemlig at forsvare af fædrelandet eller middelstandens dyder, kunne de blive inkluderet i det mandlige medborgerskab. De værdige fattige forsørgere blev en nyetableret kønsmæssig 'førstehed' i socialforsorgen i forhold til både kvinder og de fattighjælpsmodtagende mænd, da den hjælp de blev givet via de sociale særlove holdt dem uden for den almindelige fattighjælps retsvirkninger.

Det leder til et spørgsmål om, hvorfor en gruppe mænd, der netop ikke havde levet op til deres forsørgeransvar, hvilket tidligere ville have ført til en umyndiggørelse under det offentlige fattigvæsen, blev udpeget til at udgøre en særlig målgruppe ved at få en positiv særbehandling og særlige rettigheder? Forskning om det spæde demokrati i I8oo-tallet kan gøre denne positive særbehandling af'forfejlede' forsørgere begribelig, da den mandlige medborger i midten af i80o-tallet blev konstitueret i relation til sine pligtydelser overfor det fremvoksende demokratiske borgersamfund. Når det at udfylde forsørgerrollen svigtede, kunne det at leve op til at være værdig, det vil sige at tilstræbe at efterleve middelklassedyder samt det faktum, at trangen ikke var selvforskyldt, gøre selv den forfejlede forsørgerposition 
til en inkluderende faktor for mændene. Samtiden syntes at søge at bevare de værdige trængende forsørgere som ansvarlige medborgere gennem socialhjælpen.

I I80o-tallets midte hjalp det offentlige fattigvæsen mange typer af trængende, og fattigvæsenet hjalp mange børn, udarbejdsføre, gamle og børn, men de valgte analysekategorier i nærværende undersøgelse, især forsørgerrollen, åbner særligt op for at indfange en betydelig kønsændring i forsorgens uddelingsstrategi over tid. Igennem forsørgerrollen afdækkes det, at der skete en retorisk, men også i praksis, delvis inkludering af den mandlige forsørger som værdig trængende, der kunne modtage særlig hjælp af det offentlige eller den private filantropi uden rettighedstab.

\section{Supporting the Poor Worthy Men! Gendered Changes in the Distribution Strategy of Danish Relief Policies and Social Policies, 1785-1870}

The purpose of this article is to examine a remarkable change - not yet explored from a gender perspective - which occurred during the Three Year War (I848-5I) as both the social legislation and philanthropic associations started to seek to help male providers. The purpose of this shift was to ensure that these men could fulfill their role as responsible providers for themselves and their family. This new distribution strategy continued in the time to come in the philanthropic associations and the temporary social legislation introduced in Denmark in the r95os.

This strategy seeking to support the male, poor and responsible breadwinners represented a significant change, as the strategy until the middle of the rgth century entailed an intention to support women, children, the sick and the elderly. In order to explore this change, this article presents an analysis including central categories in social history. These categories are "need," "worthiness" and "the breadwinner role," which are examined from a gender perspective.

The analysis suggests that the introduction of the "respectable male breadwinner position" as a new target group in the field of public care accelerated the development of poor relief into social policies.

The material used in the study consists of published legislation, annual reports, literature from the public relief as well as from private philanthropic associations. Furthermore, archival material consisting of handwritten letters, meeting summaries, reports and negotiation protocols are also included.

Keywords: Gender, Breadwinner Role, Distribution Strategy, Social Policy, Poor Policy, Public Relief 


\section{Noter}

I Se for eksempel Christina Florin, Kampen om Katedern. Feminiserings- och professionaliseringsprocessen inom den svenska folkskolans lärakår 1860-1906, Umeå 1987; Gro Hagemann, Feminisme og historieskrivning. Inntryk fra en reise, Oslo 2003; Inger Lyngdrup Nørgård, "Mænd i historier om ligestilling: det kønsopdelte arbejdsmarked i r8oo-tallet", Temp 20IO:I.

2 Historiker Peter Wessel Hansen giver en definition på middelstand i I700- og I800-tallet "Med middelstandsbegrebet kunne man udtrykke det økonomiske, sociale og kulturelle værdifællesskab, som borgerstanden havde med de midterste lag af den gejstlige stand, militærstanden og især embedsstanden. Udtrykket 'borger- og embedsstanden' synes således at have været anvendt som et smallere synonym til middelstanden”. Peter Wessel Hansen, Den Skjulte Fattigdom, Københavns Universitet 2013, s. 54.

3 Harald Jørgensen, Studier over det offentlige Fattigvasens historiske Udvikling i Danmark $i$ det I9. Aarbundrede, København 1975 (1940), s. 97-99.

4 Kjeld Philip, Staten og Fattigdommen, København I947.

5 Anne-Lise Seip, Sosialhjelpstaten blir til: norsk sosialpolitikk I740-I920, Oslo I984, s. 70; Søren Kolstrup, "Fattiglovgivningen fra I803-189I", i Dansk Velfardshistorie, Jørn Henrik Petersen \& Klaus Petersen \& Niels Finn Christiansen (red.), Odense 20Io, s. 244-248.

6 Thecda Skocpol, Protecting Soldiers and Mothers. The Political Origins of Social Policy in United States, Cambridge \& Massachusetts I992, s. IO2-IIo.

7 Karin Lützen, Byen Tammes, København 1998, s. I4-16, I79.

8 Hans Christian Johansen \& Søren Kolstrup, "Dansk fattiglovgivning indtil r803”, i Dansk Velferdshistorie, Jørn Henrik Petersen \& Klaus Petersen \& Niels Finn Christiansen (red.), Odense 2oro, s. 174; Keld Mikkelsen, "Københavns Fattigvæsen 1770-1840”, i Meddelelser om Kobenhavn Patrioter E Fattigfolk 2005:I, s. 69; Rachel Fuchs, Gender and Poverty in Nineteenth-Century Europe, New York 2005, s. II-I3.

9 Fuchs 2005, s. 9-I4.

Io Inger Lyngdrup Nørgård, Beskyt de vardige fattige! Opfattelser og behandling af fattige i velgørenhed, filantropi og fattigvesen i København I770-I874, Odense 2017.

II Anette Faye Jacobsen, Husbondret: rettighedskulturer i Danmark, I75O-I92O, København, 2008, s. $137-\mathrm{I} 38$.

I2 Nina Koefoed, Besovede kvindfolk og ukarlige barnefadre. Kon, ret og sadelighed i I $_{700-t a l l e t s}$ Danmark, København 2008, s. 233.

I3 Nørgård 20IO, s. I49.

I4 Koefoed 20I4, s. I63.

I5 Inger Marie Hyldgaard \& Tina Knudsen Jensen \& Hanne Schaumburg Sørensen \& Jørgen Smidt-Jensen \& Palle Kirk, Randers. Fra handelsplads tilstorkommune, Iоoо-I975, Randers 2002, s. 6I-99.

I6 Nørgård 20I7, s. 49.

I7 Først i 89 I fik Danmark en fattiglov, der gjaldt for hele landet, indtil da var fattiglovgivningen delt op i tre; en for landet, en for købstæderne og en for København. Johansen \& Kolstrup 2oro, s. $185-\mathrm{I} 98$.

I8 Bronislaw Geremek, Den europeiske fattigdomens betydelse, Stockholm 1991, s. I4-36.

I9 Holmens Sogns Plejekommission, Regnskab over Indtagt, Udgivt og Beholdning for Holmens Sogns Arbeidshuus, København I799, s. 3.

20 Et Pro Memoria brev (23/3 I789) sendt fra plejekommissionen for vor Frue Sogn til Københavns Magistrat afspejler samme fokus på især at hjælpe de fattige gamle og de fattige børn. Brevkopibog for Vor Frue Plejekommission (23/9 I786-Io/5 I799). Københavns Stadsarkiv: FVIo7B, s. I7-I8. 
2I Holmens Sogns Plejekommission, Regnskab over Indtagt, Udgivt og Beholdning for Holmens Sogns Arbeidshuus, tilligemed Regnskabet for Pleie=Anstalten til den $3_{\text {I December }}$ I794, København I795, s. 20-26.

22 Snæbiørn Asgeyrsen Stadfeldt, Beskrivelse over Randers Købstad, København 1976 (I804), s. $253-265$.

23 Hansen 20I3, s. I5-I6.

24 Patriotismen indeholdt en ide om borgerdydsånd, hvor man burde udøve samfundsengagement, blandt andet gennem aktiviteter der hjalp de fattige ud af deres fattigdom. Juliane Engelhardt, Borgerskab og Fallesskab, København 2oro, s. 244.

25 Kongeligt approberet Plan for Fattigvesenets Indretning og Bestyrelse i Staden Kiøbenhavn, København 1799, København, kapitel I, §I, kapitel 3, §31.

26 Foredrag, skriftligt, af socialinspektør Peter Nikolaj Lehmeier, 19I9. Randers Fattigraesens Historie, Randers Stadsarkiv A36o, s. 8-9.

27 "Reglement for Fattigvæsenets provisoriske Indretning og Bestyrelse i Danmarks Kiøbstæder 5. juli r803", Schous Forordninger, X111 Deel København I804, afsnit 3, §II.

28 Kolstrup 20IO, s. 208-2I4.

29 Mikkelsen 2005, s. 7I-73.

30 Randers Kjøbstæds Fattigvæsen, Regnskab over Randers Kjøbstads Fattigvasens Indtegter og Udgivter fra Ist januar til 3 Ite decbr. I8Ig, Randers I820, upagieret indledning.

3I Nørgård 20I7, S. I5I-I53.

32 Mikkelsen 2005, s. 72-73.

33 Randers Kjøbstæds Fattigvæsen, Regnskab for Randers Kjøbsteds Fattigreesen for Aar I8I8, Randers I820, s. I4-I5, 44-6o.

34 Randers Kjøbstads Fattigvæsen, Regnskab over Randers Kjøbstads Fattigveasen for Aaret I847, Randers 1948, s. 32-50.

35 Hans Marius Hammeleff, Frimodige Betankninger over Kiøbenhavns Fattigvasen, København I8I9, s. II-I2; Carl Holger Visby, "Nogle Bemærkninger om de Fattige i Kjøbenhavn", Fadrelandet, 24, 25/10 I845.

36 Lützen 1998, s. I79, 203-205.

37 Andreas Kierullf, Betankning og Indstilling af 29/5 1832 til det Kgl. danske Kancelli om Ladegaardens Indretning, Københavns Stadsarkiv FV I42A, s. 19-20, $36-37$; Kjøbenhavns Borgerrepræsentation, Kjøbenhavns Borgerrepresentanters Forhandlinger, København I842, s. 176 .

38 Se Meddelelser om Legater og Stiftelser under Randers Amtsraads Tilsyn, Randers I88I.

39 Centralkomiteen af 1848, Forhandlingsprotokol for Centralkomiteen $1848-1956$, m.m. I-3, Rigsarkivet Io244, pakke I, s. I-2.

40 Skocpol I992, s. IO2-IIO.

4I Kolstrup 2010, s. 246; Jørgensen 1975, s. 97-I04.

42 Nina Koefoed, "Social Responsibilities in the Protestant North: Denmark and Sweden", i The Dynamics of Religious Reform in Northern Europe I780-I920 Volume IV: Charity and Social welfare, Joris van Eijnatten \& Nigel Yates \& Leen van Molle (red.), Leuven 20I7, s. 260.

43 Koefoed, 2014, s. I62-163.

44 Rigsdagstidende. Forhandlinger paa Folkethinget, København I850, 1øbenumre II97-II99.

45 Rigsdagstidende $\mathrm{I} 850$, løbenummer $\mathrm{I} 2 \mathrm{O} 3$.

46 Rigsdagstidende 1850, løbenumre 1689-1702.

47 Foreløbig Lov om Forsørgelsen aftjenstgjorende Militaires Familier, Forhandlingsprotokol I863-I864, Komiteen til uddeling til indkaldte soldaters familier, Randers Raadstue, Rigsarkivet, 2009/ı08. 
48 Forhandlingsprotokol $1863-\mathrm{I} 864$, Komiteen til uddeling til indkaldte soldaters familier, Randers Raadstue, Rigsarkivet, 2009/108, s. I-3.

49 Brev (16/I2 I863) fra Kiel fra M. Wellow, Forhandlingsprotokol I863-I864, Komiteen til uddeling til indkaldte soldaters familier, Randers Raadstue, Rigsarkivet, 2009/ı08.

50 Kolstrup 20I0, s. 246-47.

$5^{1} \quad$ Rigsdagstidende. Folkethinget Forhandlinger, København I853-54, løbenummer 344.

52 Kjøbenhavns Borgerrepræsentation, Kjøbenhavns Borgerrepresentanters Forhandlinger, København I855, s. 206.

53 Nørgård 20I7, s. I98.

54 Nørgård 2017, s. 193-198.

55 Borgerrepræsentationen: Forhandlingsprotokol I838-I868, Borgerrepræsentationen, Randers Raadstue, 555-556: 1847-1860, Rigsarkivet, mødereferat (27/2 I855) \& mødereferat (I2/3 I855).

56 Koefoed 20I4, s. I73; Lützen I998, s. I73-I79.

57 Borgerrepræsentationen: Forhandlingsprotokol I838-I868, Borgerrepræsentationen, Randers Raadstue, 555-556: 1847-I860, Rigsarkivet, mødereferat (23/I I854).

58 Inger Lyngdrup Nørgård, "The role of charity in public relief, 1708-I871: Copenhagen as case", Scandinavian Journal of History, 2018:43.

59 Koefoed 20I7, s. 26I-262.

60 Centralkomiteen af 1867 , Forhandlingsprotokol for det af Centralcomiteen nedsatte Udvalg angaaende Organiseringen af et frivilligt Fattigvasen $i$ Kjöbenhavn I866-I867, Foreningens Forgængere, Københavns Understøttelsesforening, PI-I87.547, Privatarkiver, Københavns Stadsarkiv, s. 9, 23, 27, 40-4I. Kvinde- og kønshistorikere har bidraget til udforskningen af filantropiens blomstringstid i r8oo-tallet, se for eksempel Birgitta Jordansson \& Tinne Vammen (red.), Charitable Women - Philanthropic Welfare I780-1930: a Nordic and Interdisciplinary Anthology, Odense 1998; Sjöberg, Marja Taussi \& Tinne Vammen (red.), På tröskeln till välfärden. Välgörenhetsformer och arenor i Norden I800-I930, Stockholm 1995. Centralkomiteen af I867, Betankning fra det af Centralcomitten nedsatte Udvalg angaaende Organisationen af et frivilligt Fattigvesen i Kjøbenhavn, København I867, s. 26-27.

6I Centralkomiteen af 1867 opstod omkring nogle af de samme mænd, der var med i Centralkomiteen af 1848 .

62 Meddelelser om Randers alm. Understottelsesforening af Bestyrelsen oktober I869, Randers I869, s. I-7.

63 Meddelelser om Randers alm. Understottelsesforening af Bestyrelsen oktober I869, s. 8.

64 Aarsberetning fra Kjøbenhavns Understottelsesforening. For Aaret fra ${ }_{I}$ November ${ }_{1874}$ til $_{3 I}$ Oktober 1875 , København 1876, s. 2-IO.

65 Aarsberetning fra Kjøbenhavns Understottelsesforening. For Aaret fra ${ }_{I}$ November ${ }_{1874} \mathrm{til}_{3^{I}}$ Oktober 1875 I876, s. I6.

66 Nina Koefoed, "Performing Male Political Citizenship", i Gender in Urban Europe. Sites of Political Activity and Citizenship, I750-1900, Krista Cowman \& Nina Koefoed \& Åsa Karlsson Sjögren (red.) New York, 20I4; Leonora Lottrup Rasmussen, ”Fattighaver og forhandlinger af medborgerskab. Et studie af forhandlingen mellem fattighjælpsmodtager og fattigudvalg i tiden efter 1849", Temp 2018:I7.

67 Jytte Larsen, Også Andre Hensyn. Dansk Ligestillingshistorie 1849-1915, Aarhus 2010, s. $86-88$.

68 Nina Koefoed, "Demokrati og medborgerskab", Fortid og Nutid 2008:4, s. 258, 274-275.

69 Jørn Henrik Petersen \& Klaus Petersen, "Sammenfatning og perspektivering", i Dansk Velfardshistorie, Jørn Henrik Petersen \& Klaus Petersen \& Niels Finn Christiansen, (red.), Odense 2oro, s. 578. 